\title{
リジンおよびスレオニンの添加効果におよぼす米の炊飯の影響
}

\section{Modification of Supplementary Effects of L-Lysine and L-Threonine by Pre-gelatinization of Polished Rice}

\author{
国立栄養研究所応用食品部(Division of Food Processing, The National Institute of Nutrition) \\ 見目 明継 (Akitsugu Kenmoku) 岩尾裕 之 (Hiroyuki Iwao)
}

The effects of pre-gelatinization of polished rice on the supplementary effects of L-lysine or L-lysine and L-threonine in the growing rats were studied.

Pre-gelatinization was highly effective in the growth of weanling rats fed the diet supplemented without any amino acid. The pre-treatment of rice protected the unfavorable effects of $0.4 \% \mathrm{~L}-1 \mathrm{ysine}$ hydrochloride fortification on body weight gain, food efficiency, weight of organs and of retroperitoneal fat, and fatty acid composition of the adipose fat, whereas the same treatment of rice showed almost no influences in the rats fed the diet supplemented with L-lysine and L-threonine. The influences of either L-lysine or L-lysine and L-threonine were noticeable in the rats fed the raw-polished rice diets. From the results obtained, it was demonstrated that the pre-gelatinzation of rice improved the nutritive value in the growing rats.

精白米たん白質の栄養価拉よび必須了ミノ酸補足の効果に関し，これまで多くの研究がなされてきた。これ らの報告によれば，米は必須アミノ酸のらちリジン含有量が特に低い(1)2) にもかかわらす゚, これの単独添加に よる改善効果については, Rosenberg 打よび Culik の報告 ${ }^{3)}$ 以外ほとんど否定的な報告() 6) である。

Pecora 预よび Hundly ${ }^{4)}$ は米にリジン怙よびスレオニンを同時に添加すると, 添加效果が顕著であること を示した。これらの研究結果はほとんど精白米を用いて得られたものであり, 飯についてはわずかに Rosen. berg 扣よび Culik の乾飯 ${ }^{3)}$ に関する報告がみられるのみである。乾飯は飯を通風乾燥して製するので, 精白 米にくらべ水分含有率が低く, 相対的に水以外の他成分の含有率が高い。また，ゼラチン様に硬い。この理由 によるためか, Rosenberg らは精白米と乾飯を直接同時に比較していない。

このように米扣よび米にたいする必須了ミノ酸補足効果に関し, 精白米と炊飯したものを同時に相互比較し た報告がみあたらない。とこで今回は精白米の水分含有量と等しくなるよう調製した凍結乾燥飯を用い，炊飯 の影響ならびに精白米と凍結乾燥飯にたいするリジンおよびスレオニン添加の影響を比較検討し, 得られた結 果を報告する。

\section{実験}

精白米：山形県産「ささにしさ」種の玄米を標準精米したもの。飼料調製にあたっては精白米をらす型粉砕 機で粉砕し，20メッシュのふるいを通過した部分を用いた。

凍結乾燥飯 : 精白米を市販の圧力式自動ガス炊飯器により点火前の浸漬30分間, むらし30分間の条件で炊飯 した。な物，炊き水には蒸留水を用いた。この飯を凍結乾燥処理して凍結乾燥飯を得た。飼料調製にあたって は精白米の場合に準じて涷結乾燥飯を粉砕機で粉末化し, 水分含有量が下記のように精白米に等しくなるよう 調整して用いた。凍結乾燥飯粉に必要量の蒸留水を噴霧器で徐々に噴霧しつつ良く撸拌してから, ポリェチレ 


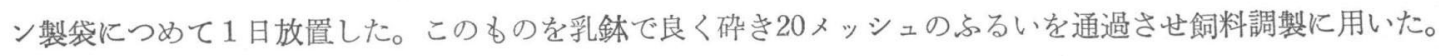

飼料 : 表に示した材料を良く混合して実験に用い

た。飼料に添加した必須アミノ酸は Lーリジン塩酸 塩および Lースレオニンの 2 種に限定した。添加量 は飼料 $100 \mathrm{~g}$ に対し Lーリジン塩酸塩 0.1 および $0.4 \mathrm{~g}$, ならびに L-スレオニン $0.1 \mathrm{~g}$ と L-リジン塩酸塩 $0.4 \mathrm{~g}$ の同時添加の 3 種類とした。

実験動物および飼育方法 : 生後 3 週間のウィスタ 一系雄シロネズミを日本ラット株式会社より購入 し, 乳カゼイン $15 \%$, 大豆油 $10 \%$, アルファコーン スターチを主体とし，ビタミンおよび無機質を十分 含さ予備飼育飼料で 7 日間飼育した後，1群 6 匹ず つの 8 群に分け実験に供した。なお, 各群の平均体 重ならびに予備飼育期間中の体重増加量はほぼ等し くなるよう配虑した。

動物の飼育は室温 $23^{\circ} \mathrm{C}$, 相対湿度 $55 \%$ に保持し てかり, 昼12時間, 夜12時間に自動設定してある飼 育室で予備飼育 7 日間, 実験飼育 14 日間行なった。
Table 1. Composition of the test diets

\begin{tabular}{lrrrr} 
& \multicolumn{5}{c}{ Diet (g) } \\
\cline { 2 - 5 } Constituent & I & II & III & IV \\
\hline Rice powder $^{\text {a) }}$ & 90 & 90 & 90 & 90 \\
Soybean oil $^{\text {b) }}$ & 5 & 5 & 5 & 5 \\
Salt mixture $^{\text {c) }}$ & 4 & 4 & 4 & 4 \\
Vitamin mixture $^{\text {d) }}$ & 0.85 & 0.85 & 0.85 & 0.85 \\
Choline chloride & 0.15 & 0.15 & 0.15 & 0.15 \\
L-Lysine HCl & & 0.1 & 0.4 & 0.4 \\
L-Threonine & & & & 0.1
\end{tabular}

a) Raw-polished or pregelatinized rice powder.

b) Mixed with vitamin A palmitate, vitamin $\mathrm{D}$ and $\mathrm{dl}-\alpha$-tocopheryl acetate dispersed in water to provide 6000 I.U. and 600 I.U. and $100 \mathrm{mg} / \mathrm{kg}$ of the diet, respectively, prior to preparation of the diet.

c) This was identical with Harper's mixture (A. E. Harper: J. Nutr., 68, 405 (1959)).

d) This was also identical with Harper's mixture, but lactose was used as a bulking agent.

飼料および水は自由に捸取させた。体重は隔日毎に, 飼料の投与, 残量, こぼし量の測定は毎日一定時刻に行 なった。

臓器重量測定 : 実験飼育終了後, 動物を断首して殺し, 肝臓, 菌丸ならびに後腹壁脂肪を摘出し直ちに重量 を測定した。

脂肪酸組成の算出: 後腹壁脂肪については, 脂肪酸をガスクロマトグラフィーにより分離7)し, 面積比較法 により組成の算出を行なった。

実験結果の推計学的処理 : 実験值は平均值ならびに標準誤差の算出を行な 5 と同時に $\mathrm{t}$ 檢定を行なった。

\section{実験結果ならびに考察}

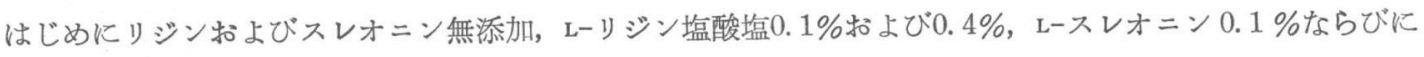
Lーリジン塩酸塩 $0.4 \%$ 同時添加の 4 種につき，精白米と凍結乾燥飯を相互比較し，それぞれの場合に拈ける 炊飯の影響を(A)体重増加および飼料摂取量, (B)葴器および後腹壁脂肪重量, (C) 後腹壁脂肪の脂肪酸組成 について検討した。次いで精白米にたいするリジンめるいはリジンおよびスレオニンの同時添加の際認められ る影響が，凍結乾燥飯の昜合にも同様に認められるか否か検討した。

A) 体重増加扣よび飼料摂取量

1）炊飯の影響：アミノ酸無添加ならびにレーリジン塩酸塩 $0.4 \%$ 添加飼料を投与した 2 種の群で，涷結乾燥 飯が精白米よりも体重増加量, 体重増加率および飼料摂取量, 飼料効率に拈いて優る結果を示した。しかし, Lーリジン塩酸塩0.1\%添加, および レースレオニン $0.1 \%$ とーリジン塩酸塩 $0.4 \%$ を添加した飼料で飼育した場合 には，前述のごとき炊飯の影響は明らかでなかった（表 $2 ， 3$ )。 
Table 2. Body weight gain and the gain ratio of weanling rats fed on raw-polished or pre. gelatinized-freezed-dried rice diet supplemented with or without L-Lysine hydrochlori. de and L-Threonine for 14 days

\begin{tabular}{|c|c|c|c|c|c|c|c|}
\hline \multirow{3}{*}{ Supplement } & \multirow{3}{*}{$\begin{array}{c}\text { Number } \\
\text { of } \\
\text { rats }\end{array}$} & \multicolumn{6}{|c|}{ Body weight } \\
\hline & & \multicolumn{2}{|c|}{$\begin{array}{l}\text { Initial } \\
(\mathrm{g} / \mathrm{rat})\end{array}$} & \multicolumn{2}{|c|}{$\begin{array}{c}\text { Gain } \\
\text { (g/rat) }\end{array}$} & \multicolumn{2}{|c|}{$\begin{array}{c}\text { Gain ratio } \\
\text { (gain/initial body weight/rat) }\end{array}$} \\
\hline & & Raw & Gelatinized & Raw & Gelatinized & Raw & Gelatinized \\
\hline None & 6 & $66.0 \pm 1.00^{\mathrm{a})}$ & $66.5 \pm 0.96$ & $11.4 \pm 0.81$ & 19. $3 \pm 1.20$ & $0.17 \pm 0.013$ & $0.29 \pm 0.018$ \\
\hline $0.1 \%$ L-Lys $\mathrm{HCl}$ & 6 & $66.6 \pm 2.42$ & $66.5 \pm 0.96$ & $14.6 \pm 1.75$ & $16.5 \pm 2.45$ & $0.22 \pm 0.031$ & $0.24 \pm 0.033$ \\
\hline $0.4 \%$ L-Lys $\mathrm{HCl}$ & 6 & $67.2 \pm 1.72$ & $66.5 \pm 0.92$ & $6.0 \pm 0.95$ & $12.3 \pm 0.92$ & $0.09 \pm 0.015$ & $0.18 \pm 0.029$ \\
\hline $\begin{array}{ll}0.4 \% & \text { L-Lys } \mathrm{HCl}+ \\
0.1 \% & \text { L-Thr }\end{array}$ & 6 & $66.5 \pm 1.18$ & $66.5 \pm 0.96$ & $62.2 \pm 4.74$ & $59.3 \pm 6.27$ & $0.94 \pm 0.072$ & $0.91 \pm 0.104$ \\
\hline
\end{tabular}

a) Standard error of the mean.

2)リジン拈よ びスレオニン添加の 影響 : 精白米飼料群 についてみるとLーリ ジン塩酸塩 $0.1 \%$ 添 加は, Rosenberg $ら^{3)}$ が報告したごとき著 明な体重増加をもた らさなかった。 Lーリ ジン塩酸塩添加量を 0. $4 \%$ に高めたとこ
Table 3. Food consumption and efficiency of weanling rats fed on rawpolished or pre-gelatinized-freezedried rice diet supplemented with or without L-Lysine hydrochloride and L-Threonine for 14 days

\begin{tabular}{|c|c|c|c|c|}
\hline \multirow{2}{*}{ Supplement } & \multicolumn{2}{|c|}{$\begin{array}{l}\text { Food intake } \\
\quad(\mathrm{g} / \mathrm{rat})\end{array}$} & \multicolumn{2}{|c|}{$\begin{array}{c}\text { Food efficiency } \\
\text { (g food intake/g gain/rat) }\end{array}$} \\
\hline & Raw & Gelatinized & Raw & Gelatinized \\
\hline None & $125.8 \pm 3.85^{a)}$ & 148. $0 \pm 3.23$ & $11.2 \pm 0.56$ & $7.8 \pm 0.39$ \\
\hline $0.1 \%$ L-Lys $\mathrm{HCl}$ & $131.7 \pm 2.70$ & $134.8 \pm 8.02$ & $9.5 \pm 0.91$ & $8.7 \pm 0.75$ \\
\hline $0.4 \%$ L-Lys $\mathrm{HCl}$ & $111.8 \pm 3.86$ & $125.6 \pm 4.16$ & $20.4 \pm 3.05$ & $10.4 \pm 0.62$ \\
\hline $\begin{array}{ll}0.4 \% & \text { L-Lys } \mathrm{HCl}+ \\
0.1 \% & \text { L-Thr }\end{array}$ & $216.9 \pm 9.05$ & 215. $0 \pm 14.4$ & $3.5 \pm 0.11$ & $3.7 \pm 0.20$ \\
\hline
\end{tabular}

a) Standard error of the mean.

ろ, 体重増加量は無添加群のとれよりも劣る結果を示した。Lーリジン塩酸塩 $0.4 \%$ よび Lースレオニン $0.1 \%$ の同時添加飼料を投与したところ，Lーリジン塩酸塩 $0.4 \%$ 添加時にみられた低い体重増加は改善され，Pecora 扰よび Hundley ${ }^{4)}$ の示したごとくいちじるしい体重増加が認められた（表 2 ）。飼料摂取量は Lーリジン塩酸 塩 $0.1 \%$ 添加によりいくぶん増加する傾向を示したが，添加量を $0.4 \%$ 高めたところ無添加のとれよりも少な くなった。しかし，L-リジン塩酸塩 $0.4 \%$ に加えて L-スレオニン $0.1 \%$ を添加したところ， Lーリジン塩酸塩0.4 \%添加時に認められた影響はなくなり，摂取量のいちじるしい増加が認められた。飼料効率はリジンおよびス レオニンの同時添加群が最も良好で, 次いで L-リジン塩酸塩 $0.1 \%$ 添加群, 無添加群となり, L-リジン塩酸塩 $0.4 \%$ 添加群が最低值を示した（表 3 ）。

凍結乾燥飯飼料群に和いて得られた結果（表 2,3 ）は, L-リジン塩酸塩 $0.1 \%$ 添加群の体重増加量, 飼料 摂取量が無添加群のそれよりいくぶん少なかったことを除き，すべて精白米飼料の場合に類似していた。しか しアミノ酸添加の影響は精白米飼料の場合より小さかった。

飯のでん粉はアルファ化度が高い88 ことにより精白米といちじるしく異なっている。体重増加量および飼料 摂取量にたいし米の炊飯の影響が明らかに認められたことは，アルファでん粉がペータでん粉より優っている ことを示しているものと考えている。この点に関しては別に報告する予定である。 
一方，精白米たん白質の消化吸収率は良好 ${ }^{910)}$ であることから，たん白質の消化吸収率が米の炊飯により改 善されたのではないかということに関しては，特に考虑しなくても良いのではないか。

B）臓器および後腹壁脂肪重量

肝臓，凨丸および後腹壁脂肪重量を体重 $100 \mathrm{~g}$ 当りに算出し，この值を用いて，炊飯ならびにリジンおよび スレオニン添加の影響をみた。

1) 炊飯の影響：アミノ酸無添加飼料群間では, 凍結乾燥飯飼料群の肝藏および後腹壁脂肪重量が, 精白米 飼料群のそれより大なる傾向を示した。しかし殬丸重量に差はみられなかった。Lーリジン塩酸塩 $0.1 \%$ 添加群 間では肝臓，䓿丸および後腹壁脂肪重量のいずれにおいても，米の炊飯の影響が明らかでなかった。レーリジン 塩酸塩 $0.4 \%$ 添加群間では精白米群の肝臓重量が大きく, 鼻丸量量に差がなく, 後腹壁脂肪重量は凍結乾燥飯 群が高值を示した。Lーリジン塩酸塩 $0.4 \%$ ，Lースレオニン0.1\%の同時添加群間では肝臓，堅丸および後腹壁脂 肪重量のいずれに拈いても，炊飯の影響が認められなかった（表 4)。

Table 4. Tissue wieghts of rats 14 days after being fed the diet of raw-polished or pre-gelatinized and freezed-dried rice supplemented with or without $\mathrm{L}$-Lysine hydrochloride and L-Threonine

(g/100 g Body weight)

\begin{tabular}{|c|c|c|c|c|c|c|}
\hline \multirow{2}{*}{ Supplement } & \multicolumn{2}{|c|}{ Liver } & \multicolumn{2}{|c|}{ Testicles } & \multicolumn{2}{|c|}{ Retroperitoneal fat } \\
\hline & Raw & Gelatinized & Raw & Gelatinized & Raw & Gelatinized \\
\hline None & $3.66 \pm 0.17^{\mathrm{a})}$ & 4. $39 \pm 0.33$ & $0.77 \pm 0.08$ & $0.91 \pm 0.13$ & $1.08 \pm 0.06$ & $1.25 \pm 0.10$ \\
\hline $0.1 \%$ L-Lys $\mathrm{HCl}$ & $4.79 \pm 0.22$ & 4. $42 \pm 0.14$ & $0.84 \pm 0.12$ & $0.74 \pm 0.06$ & $0.89 \pm 0.12$ & $1.00 \pm 0.09$ \\
\hline $0.4 \%$ L-Lys $\mathrm{HCl}$ & $5.02 \pm 0.20$ & 4. $36 \pm 0.15$ & $1.02 \pm 0.09$ & $0.94 \pm 0.11$ & $0.51 \pm 0.10$ & $0.91 \pm 0.06$ \\
\hline $\begin{array}{ll}0.4 \% & \text { L-Lys } \mathrm{HCl}+ \\
0.1 \% & \text { L-Thr }\end{array}$ & $4.28 \pm 0.07$ & $4.29 \pm 0.08$ & $0.84 \pm 0.07$ & $0.85 \pm 0.07$ & $1.32 \pm 0.08$ & $1.24 \pm 0.06$ \\
\hline
\end{tabular}

a) Standard error of the mean. Figures are represented the average of 6 rats.

2) リジンおよびスレオニン添加の影響 : 米にたいするLーリジン塩酸塩添加の影響は肝臓重量の場合精白米 群に認められ, 後腹壁脂肪重量の減少は精白米および凍結乾燥飯群の双方で認められた。おたLーリジン塩酸塩 $0.4 \%$ おる゙ ᄂースレオニン $0.1 \%$ 同時添加の影響は, 精白米群の場合肝臓および後腹壁脂肪重量に, 凍結乾 燥飯群の場合は後腹壁脂肪重量にのみ認められた。以上のごとくリジン単独めるいはリジンとスレオニンの同 時添加の影響は, 精白米群に扣いて凍結乾燥飯群よりいらじるしく, 後腹壁脂肪重量が米へのリジン単独添加 で減少することを示した（表 4 ）。この結果は精白米飼料にリジンを添加しても肝缄脂肪含有量は減少しない が，リジンと共にスレオニンを添加すれば減少する5゙ことと対照的である。リジン単独添加の場合にみられた 後腹壁脂肪重量の減少傾向は, リジン添加量を増したとき飼料摂取量の減少する傾向がいちじるしかった精白 米群に拉いても大であった（表 4 ）。

飼料摂取量と後腹壁脂肪重量との関係（図 1) および体重増加率と後腹壁脂肪重量との関係（図 2）は，リ ジンおよびスレオニンの同時添加群を除いたとき, 後腹壁脂肪重量の多少が体重増加率の高低すなわち飼料摂 取量の多少と密接に関係していることを示している。なお，リジンおよびスレオニンの同時添加が精白米飼料 ならびに凍結乾燥飯飼料の両者に㧍いて,いちじるしい飼料摂取量の増加をもたらし体重増加率も高くなった （図1）にもかかわらず，後腹壁脂肪重量アミノ酸無添加飼料群の示した值と変りなかったことは, 飼料たん 白質のアミノ酸バランスが劣るときにのみ飼料摂取量の多少, 体重増加率の高低が後腹壁脂肪重量の多少に影 


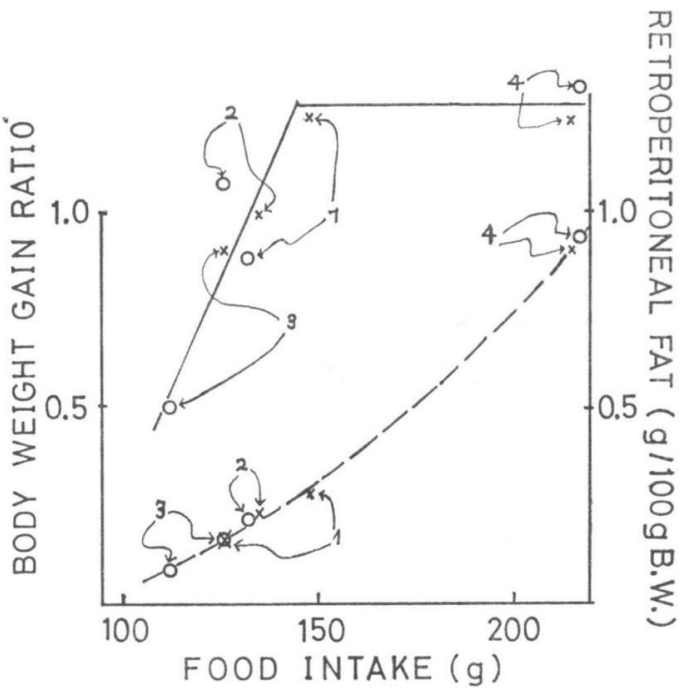

Fig. 1 Relationships between food intake and body weight gain ratio, and between food intake and weight of retroperito. neal fat.

.. Body weight gain ratio, - weight of retroperitoneal fat. $\bigcirc$ : Raw-polished rice, $\times$ : pre-gelatinized-freezedried rice. $1: \mathrm{Wi}$ thout fortification, $2: 0.1 \%$ L-Lys $\mathrm{HCl}, 3$ : $0.4 \%$ L-Lys $\mathrm{HCl}, 4: 0.4 \%$ L-Lys $\mathrm{HCl}$ and $0.1 \%$ L-Thr.

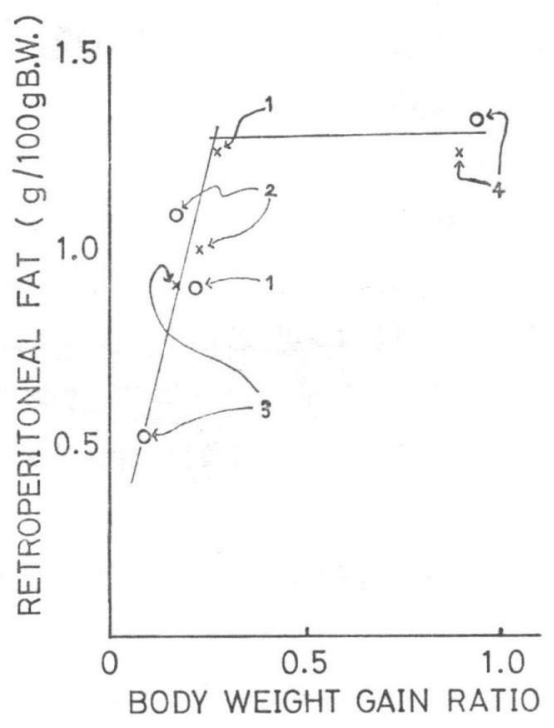

Fig. 2 Relatioship between body weight gain ratio and weight of retroperitoneal fat.

$O$ : Raw-polished rice, $X$ : pre-gelatinized -freezedried rice. 1 : Without fortification, $2: 0.1 \%$ L-Lys $\mathrm{HCl}, 3: 0.4 \%$ L-Lys $\mathrm{HCl}$, $4: 0.4 \%$ L-Lys $\mathrm{HCl}$ and $0.1 \%$ L-Thr.

響することを示しているのではないだろらか。

C) 後腹壁脂肪の脂肪酸組成

1）炊飯の影響：アミノ酸無添加，L-リジン塩酸塩0.1\%あるいは $0.4 \%$ およびLーリジン塩酸塩 $0.4 \%$ なら びに レースレオニン $0.1 \%$ 同時添加の 4 種の飼料群において, 精白米群および涷結乾燥飯群から得られた後腹 壁脂肪の脂肪酸組成に顕著な差はなかった（表 5 )。

Table 5. Fatty acid composition of retroperitoneal fat in the rats after 14 days feeding diets of raw-polished or pre-gelatinized-freezedried rice supplemented with or without L-Lysine hydrochloride and L-Threonine

\begin{tabular}{lllllllll}
\hline Supplement & $\mathrm{C}_{14}$ & $\mathrm{C}_{16}$ & $\mathrm{C}_{18: 1}$ & $\mathrm{C}_{18}$ & $\mathrm{C}_{18: 1}$ & $\mathrm{C}_{18: 2}$ & $\mathrm{C}_{18: 3}$ \\
\hline
\end{tabular}
Raw-polished rice $(\%)$

None

$2.19 \pm 0.13^{\mathrm{a})} 32.51 \pm 0.5310 .85 \pm 0.302 .99 \pm 0.17 \quad 30.58 \pm 0.5919 .01 \pm 0.771 .87 \pm 0.11$

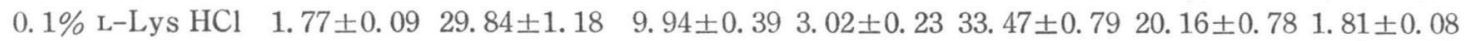

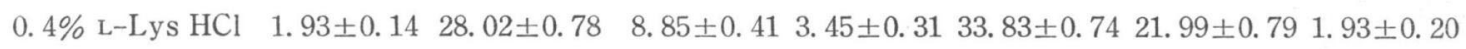

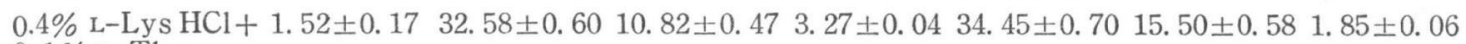
$0.1 \%$ L-Thr

Pre-gelatinized-freezed-dried rice $(\%)$

None $\quad 1.79 \pm 0.0731 .55 \pm 0.77 \quad 11.32 \pm 0.75 \quad 2.75 \pm 0.1030 .18 \pm 0.5020 .29 \pm 0.642 .12 \pm 0.05$

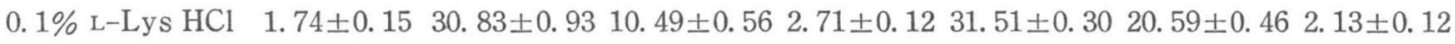
$0.4 \%$ L-Lys HCl $1.83 \pm 0.0930 .57 \pm 0.5510 .34 \pm 0.50 \quad 2.76 \pm 0.15 \quad 31.96 \pm 0.97 \quad 20.69 \pm 0.842 .02 \pm 0.15$

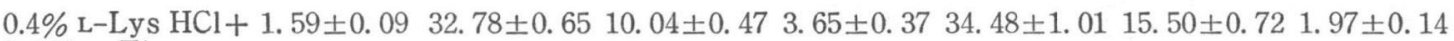
$0.1 \%$ L-Thr

a) Standard error of the mean. 
2）リジンおよびスレオニン添加の影響 : 精白米飼料にLーリジン塩酸塩 $0.1 \%$ \%るいは $0.4 \%$ 添加した場合， 後腹壁脂肪の $\mathrm{C}_{16}$ および $\mathrm{C}_{16: 1}$ 脂肪酸はリジン添加量の多いほど低值を示した。これに反し, $\mathrm{C}_{18: 1}, \mathrm{C}_{18: 2}$ 脂 肪酸はリジン添加量を増すと高くなる傾向を示した。Lーリジン塩酸塩0.4\%にLースレオニン0.1\%をさらに添加 すると, リジン単独添加時にみられた $\mathrm{C}_{16}$ 拉よび $\mathrm{C}_{16: 1}$ 脂肪酸值の低下は認められず, アミノ酸無添加時の值 とほぼ等しい值となった。 $\mathrm{C}_{18: 1}$ 脂肪酸值はLーリジン塩酸塩 $0.4 \%$ 添加時よりさらに高くなる傾向を示したが,

$\mathrm{C}_{18: 2}$ 脂肪酸値はアミノ酸無添加時よりる低值となった（表 5 )。

凍結乾燥飯飼料に L-リジン塩酸塩 $0.1 \%$ 扣よび $0.4 \%$ 添加した場合は, 精白米飼料ヘリジンを同様に添加し たときと異なり脂肪酸組成に顕著な変化がみられなかった。しかし，L-リジン塩酸塩 $0.4 \%$ と \%を同時に添加すると精白米飼料へこの 2 種のアミノ酸を添加したときと同様, $\mathrm{C}_{18}, \mathrm{C}_{18: 1}$ 脂肪酸値はアミノ 酸無添加時の值より高くなり， $\mathrm{C}_{18: 2}$ 脂肪酸值はアミノ酸無添加時の值より低くなった（表 5 )。

さきに記したように投与飼料の脂肪源ならびに含有量を等しくした飼料を摂取していたにもかかわらず, 体 脂肪量の多少を示す目安 ${ }^{11}$ となる体重 $100 \mathrm{~g}$ 当りの後腹壁脂肪重量が, 米の炊飯および飼料へのアミノ酸添 加で変化すると同時にその脂肪酸組成も変化したことは, 体成分組成が飼料の種々なる因子の影響を受けて变 化することを示していよう。

今回の実験でアミノ酸無添加凍結乾燥飯飼料群の肝臓, 堅丸ならびに後腹壁脂肪重量が, リジンおよびスレ オニンの同時添加飼料群の示した值に近似であったこと，リジン単独あるいはリジンとスレオニン同時添加に よる体重増加, 臓器重量, 後腹壁脂肪重量およびその脂肪酸組成の変化が小さかったこと, またアミノ酸無添 加群間では凍結乾燥飯飼料群の体重増加および飼料効率が精白米飼料群より優れていたことなどから，炊飯は 精白米の栄養価を向上させたものと考える。な拉，人間は食品を通常調理して食することを考虑するなら，今 回の実験結果からも食品の栄養価測定に際し, 可能なかぎり水と共に加熱した試料を用いるべきであろう。

\section{要 約}

1）幼シロネズミを用い精白米およぴこれと水分含有量を等しく調製した凍結乾燥飯にリジン単独あるいは リジンとスレオニンの両者を同時に添加し，無添加および添加時における米の炊飯の影響，ならびに精白米と 涷結乾燥飯にたいする添加の影響を体重増加量, 飼料效率, 臓器重量, 後腹壁脂肪重量ならびにその脂肪酸組 成を測定して比較検討した。

2）炊飯の影響はアミノ酸無添加時と L-リジン塩酸塩 $0.4 \%$ 添加時に特に明らかであったが, Lーリジン塩酸 塩0. $4 \%$ としースレオニン0.1\%を同時に添加した場合には，炊飯の影響が明らかでなかった。

3）飼料にリジン単独あるいはリジンとスレオニンの同時添加時にみられる影響は, 凍結乾燥飯より精白米 において顕著であった。

4) 結果を総合すると炊飯は米の栄員価を向上させると判断する。

\section{文献}

1) H. H. Mitchel, R. J. Block: J. Biol. Chem., 163, 599 (1946)

2) 科学技術庁資源調查会編：日本食品了ミノ酸組成表 (1966)

3) H. R. Rosenberg, R. Culik: J.Nutrition, 63, 477 (1957)

4) L. J. Pecora, J. M. Hundly:J. Nutrition, 44, 101 (1951)

5) A. E. Harper, M. E. Winje, D. A. Benton, C. A. Elvehjem: J. Nutrition, 56, 187 (1955)

6) 吉田, 芦田: 栄養と食糧, 20,432 (1968)

7 H. H. Hofstetter, N. Sen, R. T. Holman: J. Amer. Oil Chemist Soc., 42, 537 (1965)

8) 高居, 細川, 岩尾, 宇野, 和田 : 国立栄養研究所研究報告, 昭和38年度, 49 (1963)

9) 小柳, 鷹篇, 及川 : 栄養と食糧, 19, 256 (1966)

10) 見目, 岩尾: 準備中

11) 高居: 私信

（受付 : 昭和 48 年 8 月 21 日） 